\title{
VAŽNOST INTRINZIČNIH I EKSTRINZIČNIH MOTIVATORA KOD ODABIRA PRVOG POSLODAVCA
}

\author{
Ivana Načinović Braje \\ Dr. sc., docent, Sveučilište u Zagrebu, Ekonomski fakultet, Trg J. F. Kennedyja 6, 10000 Zagreb, Hrvatska; \\ e-mail: Ivana.nacinovic@efzg.hr
}

Ana Aleksić

Dr. sc., docent, Sveučilište u Zagrebu, Ekonomski fakultet, Trg J. F. Kennedyja 6, 10000 Zagreb, Hrvatska; e-mail: aaleksic@efzg.hr

Lucija Babok

Mag. oec;; e-mail: luche22@gmail.com

\section{SAŽETAK}

Privlačnost poslodavca utječe na želju za zapošljavanjem i radom u određenoj organizaciji pa se organizacije sve češće pokušavaju diferencirati od ostalih u sektoru te u mislima potencijalnih zaposlenika stvoriti sliku poželjnog poslodavca. Istovremeno, pojedince na akciju mogu potaknuti razni motivi, intrinzičnog i ekstrinzičnog karaktera. Surha rada je utvrditi vrstu motivacije kojom su pojedinci vođeni u ostvarivanju vlastitih ciljeva te utvrditi ulogu pojedinih čimbenika motivacije prilikom donošenja odluke o zapošljavanju u određenoj organizaciji. Ciljevi istraživanja su sljedeći: utvrditi razinu intrinzične i ekstrinzične motivacije ispitanika, uturditi važnost pojedinih obilježja poslodavca prilikom odabira prvog poslodavca te prikupiti saznanja o razlikama u poželjnim obilježjima poslodavca između ispitanika koji su intrinzično i ekstrinzično motivirani. Istraživanje je provedeno u dva navrata tijekom dviju godina korištenjem online anketnog upitnika na uzorku od 165 ispitanika, studenata diplomskih studija, prvostupnika i magistara koji ne mogu naći posao ili su u postupku stručnog osposobljavanja. Utvrđeno je da su ispitanici dominantno motivirani intrinzičnim motivima. Za visokoobrazovane mlade izrazitu važnost prilikom odabira prvog poslodavca imaju mogućnost za stjecanje iskustva u struci i dobri odnosi s kolegama, što dodatno potvrđuje visoku intrinzičnu motivaciju mladih u Hrvatskoj. Skupinu obilježja poslodavca od najmanje važnosti mladima predvode karakteristike organizacije - njena veličina i djelatnost.

Ključne riječi: intrinzična motivacija, ekstrinzična motivacija, prvi poslodavac, generacija Y 


\section{UVOD}

Jedna od značajnih karakteristika koje određuju tržište rada u 21. stoljeću, sa strane organizacija, jest rat za talente, odnosno, privlačenje kvalitetnih zaposlenika u organizacije prije konkurencije, što uključuje i mlade koji traže prvo zaposlenje. U cilju uspješnog odgovora na taj izazov organizacije teže u javnosti stvoriti imidž poželjnog poslodavca. $S$ druge strane, iz perspektive mladih posloprimaca, proces traženja posla je dinamičan proces odlučivanja u kojem radno mjesto i karakteristike organizacije utječu na konačan izbor poslodavca (Gomes, Neves, 2011; Montgomery, Ramus, 2011). Navedene karakteristike imaju izravan efekt na privlačnost organizacije kandidatu te značajno utječu na odluku o prihvaćanju ili odbijanju poslovne ponude neke organizacije. Postojeći nalazi o važnosti pojedinih obilježja poslodavaca prilikom procesa traženja posla za mlade zaposlenike, pripadnike generacije $Y^{1}$, donekle su heterogeni i upućuju na to da mladi traže poslodavce koji pokazuju brigu za zaposlenike, pružaju mogućnosti za napredovanje i razvoj karijere, ulažu u dodatno obrazovanje zaposlenika, imaju kolektivni stil upravljanja, podržavajuću i pozitivnu radnu okolinu, nude sigurnost posla, ali su društveno odgovorni, provode etične prakse i posvećuju pažnju zaštiti okoliša (Terjesen et al., 2007; Montgomery, Ramus, 2011; Guillot - Soulez, Soulez, 2014). Karakteristike organizacije poput veličine, reputacije ili djelatnosti u kojoj organizacija posluje pokazale su se manje bitnima kod izbora poslodavca (Arachchige, Robertson, 2013).

Osim karakteristika poslodavaca, prilikom odabira onog poželjnog, potrebno je uzeti u obzir i želje i potrebe pojedinaca. Smatra se da su ljudi motivirani za one oblike ponašanja koji rezultiraju zadovoljavanjem njihovih potreba. Svako čovjekovo ponašanje posljedica je djelovanja motivacijskog ciklusa koji započinje narušavanjem ravnoteže u organizmu kroz aktivaciju neke fiziološke ili psihološke potrebe (Barić, 2012). Prema teoriji samoodređenja, motivaciju uvelike određuje količina, ali i kvaliteta motivacije (Deci, Ryan, 2000). Osim toga, pokazalo se da motivacija pojedinaca ima ulogu prilikom procesa traženja posla (Viega, Gabriel, 2016). Stoga se postavlja pitanje kakva je uloga osobne motivacije mladih kod izbora prvog poslodavca, odnosno donose li mladi odluke o odabiru poželjnog poslodavca s obzirom na to jesu li intrinzično ili ekstrinzično motivirani. Istraživačka pitanja kojim je vođen ovaj rad su: (1) koji su dominantni izvori motivacije mladih, (2) koja su obilježja poslodavca važna mladima prilikom izbora poslodavca te (3) postoji li razlika između dominantno intrinzično motiviranih i dominantno ekstrinzično motiviranih mladih u pogledu poželjnih obilježja poslodavca pri izboru prvog poslodavca.

Rad se sastoji od četiri cjeline: uvoda, teorijskog pregleda, metodologije i rezultata istraživanja te zaključka. U teorijskom pregledu obrađuju se pojmovi intrinzične i ekstrinzične motivacije i motivacijskog ciklusa te privlačnosti poslodavca. Empirijski dio rada identificira dominantnu vrstu motivacije koja pojedince potiče na akciju i prikazuje čimbenike koji pojedince privlače za rad u točno određenoj organizaciji.

Generacija Y čini generaciju zaposlenika rođenih između 1980. i 2000. godine 


\section{TEORIJSKI PREGLED POJMOVA I LITERATURE}

\section{1 Intrinzična i ekstrinzična motivacija}

Čovjekovo ponašanje određeno je motivima koji ga pokreću. Motivi za pojedinu aktivnost mogu biti razni, potaknuti vlastitim potrebama, odnosno intrinzično, ili poticajima iz okoline, odnosno ekstrinzično. Intrinzična motivacija proizlazi iz zadovoljstva bavljenja pojedinom aktivnosti, dok se ekstrinzična motivacija opisuje kao sredstvo koje rezultira određenim ponašanjem, točnije, zadovoljstvo nije dobiveno iz same aktivnosti, već kao vanjska posljedica koja usmjerava prema aktivnosti (Rita et al., 2018).

Intrinzična motivacija odnosi se na činitelje zbog kojih su neke aktivnosti nagrađujuće same po sebi (Beck, 2003). Ponašanje je intrinzično motivirano ako osoba djeluje na poticaj vlastitog poriva (Rheinberg, 2004), odnosno, ako je autonomno i samoodređeno (Deci, Ryan, 2000). Intrinzična motivacija poistovjećuje se s urođenom motivacijom osoba da slijede vlastite interese te ulažu napor u traženje izazova koji će omogućiti daljnji razvoj vještina i sposobnosti (Reeve, 2010). Osim toga, obično se smatra da je motivacija zaposlenika jedan od ključnih prediktora ukupne radne uspješnosti zaposlenika. lako bi se moglo očekivati da će intrinzična motivacija, u usporedbi s ekstrinzičnom motivacijom, imati snažniji pozitivni efekt na učinak zaposlenika (Deci, Ryan, 2000), empirijska istraživanja nisu potvrdila utjecaj intrinzične motivacije na uspjeh u izvršavanju zadataka (Zhang et al., 2016). Kako bi organizacije kod zaposlenika potakle intrinzičnu motivaciju, poželjno je kreirati izazovne i zanimljive poslove koji u potpunosti iskorištavaju i razvijaju njihova znanja i vještine, ukloniti birokraciju i loše osmišljene procese, osnažiti zaposlenike za razvoj novih načina rada temeljem njihovih razlika i jedinstvenih karakteristika te poticati menadžere da odaju priznanje zaposlenicima iznad i ispod u hijerarhijskom lancu (Delaney, Royal, 2017).

Uz ekstrinzičnu motivaciju povezuje se želja da se određena aktivnost izvršava s namjerom da se ostvare pozitivne posljedice, poput nagrada, ili izbjegnu negativne posljedice u vidu kazni (Deci, Ryan, 2000). Ekstrinzična motivacija vođena je formalnim poticajima ili poticajima koji zaposlenicima donose opipljive prinose u obliku nagrada ili statusa, ali i dobivanja visoke ocjene radne uspješnosti, ostvarenje napredovanja, izloženosti višim rukovoditeljima ili vođenja tima ili projekta (Delaney, Royal, 2017).

lako intrinzična i ekstrinzična motivacija mogu djelovati istovremeno, istraživanja ukazuju da će jedan od navedenih oblika motivacije biti dominantan (Gagné, Deci, 2005), odnosno da intrinzična i ekstrinzična motivacija mogu biti negativno povezane (Kuvaas et al., 2017) te se stoga trebaju promatrati odvojeno.

\section{2 Privlačnost poslodavca}

Privlačnost poslodavca definirana je kao zamišljena korist koju potencijalni zaposlenik vidi u zapošljavanju u određenoj organizaciji (Berthon et al., 2005). Obuhvaća skup materijalnih i nematerijalnih čimbenika poput uzbudljive radne okoline, korištenja zaposlenikove kreativnosti, timskog rada, plaće i beneficija, samoaktualizacije, stjecanja i prenošenja znanja i vještina, odnosa među zaposlenicima i sličnog (Berthon et al., 2005). 
Privlačnost poslodavca utječe na želju za zapošljavanjem i radom u određenoj organizaciji te stoga privlačna organizacija postaje poželjan poslodavac za zaposlenike (Franca, Pahor, 2012). Čimbenici koji pridonose organizacijama da postanu poželjni poslodavci su raznoliki, primjerice pružanje visokog stupnja sigurnosti, povećanje buduće zapošljivosti stvaranjem reputacije poslodavca koji razvija visokokvalitetne zaposlenike i pruža im razne mogućnosti učenja, osiguranje radnih uvjeta koji pružaju balans poslovnog i privatnog života, sustav nagrađivanja koji prepoznaje i cijeni doprinose zaposlenih i osigurava konkurentnu plaću i beneficije, izazovno radno mjesto te mogućnosti za učenje i daljnji razvoj karijere (Sokro, 2012). Prema istraživanju Employer Brand Internationala iz 2014. godine najvažniji čimbenici koje organizacije prilikom privlačenja kandidata mogu naglasiti su upravo nematerijalni - mogućnost za razvoj karijere, vodstvo i radna okolina.

Organizacije mogu postati poželjni poslodavci ulažući napore u stvaranje dodane vrijednosti marke poslodavca (engl. employer brand) (Sokro, 2012). Što je poslodavac privlačniji potencijalnom zaposleniku, to se povećava vrijednost organizacijske marke(Berthon et al.,2005). Marka poslodavca određuje identitet organizacije kao poslodavca i usmjerava organizacijske vrijednosti, politike i ponašanje prema privlačenju, motiviranju i zadržavanju trenutnih i potencijalnih zaposlenika (Wilden et al., 2010). Organizacije stvaraju svoju marku kako bi lakše privukle i zadržale najtraženije zaposlenike za koje smatraju da mogu pridonijeti jačanju marke poslodavca i osigurati stalnu profitabilnost (Arachchige, Robertson, 2013). Konačno, promocija marke unutar organizacije pridonijet će povećanju lojalnosti zaposlenika, dok će je promocija marke izvan organizacije učiniti atraktivnom za potencijalne zaposlenike (Chhabra, Sharma, 2014).

Percepcija marke poslodavca varira u odnosu na dob, spol i prethodna iskustva (Jain, Bhatt, 2015). Ujedno, istraživanja pokazuju da se percepcija poslodavca i njegovih poželjnih obilježja razlikuje ovisno o generaciji kojoj pojedinci pripadaju (Reis, Braga, 2016). Generacije su određene grupe koje uobičajeno dijele godine rođenja, dob, lokaciju, al i značajne događaje koji su obilježili njihov razvoj (Kupperschmidt, 2000). Ovaj rad fokusira se na mlade, studente završnih godina studija, koji dijele slična obilježja (Mannheim, 1952) te se s obzirom na životnu dob smatraju pripadnicima generacije Y (Dries et al., 2008). Kao rezultat različitih promjena i uvjeta okoline u kojoj su odrasli, današnji studenti, a budući zaposlenici, razvili su specifične stavove i sklonosti (Oblinger, 2003). Pripadnici generacije Y su ambiciozni, orijentirani karijeri, traže profesionalne izazove, teže uspjehu i tome da ostvare značajne rezultate te traže poslodavce koji im mogu omogućiti profesionalni razvoj (Wong et al., 2008; Kong et al., 2015). U odnosu na stavove i ponašanja prethodnih generacija, generacija Y izrazito je orijentirana na postizanje rezultata i fleksibilna, iako kao jedan od važnijih čimbenika motivacije ističe i sigurnost posla (Jain, Bhatt, 2015). Ipak, i kod mladih, pripadnika generacije $Y$ postoje velike razlike u preferiranim poželjnim obilježjima poslodavaca (Arachchige, Robertson, 2013).

Kako bi organizacije privlačile najbolje kandidate, važno je znati čime su motivirani za rad. Pritom je potrebno analizirati želje i preferencije pojedinih skupina zaposlenika te uvidjeti proizlazi li njihova motivacija iz unutarnjih potreba ili su više motivirani vanjskim čimbenicima. 


\section{EMPIRIJSKO ISTRAŽIVANJE}

\section{1 Metodologija istraživanja}

U cilju analize razine intrinzične i ekstrinzične motivacije ispitanika, kao i obilježja privlačnih poslodavaca, provedeno je primarno istraživanje među ciljanom skupinom - studentima diplomskih studija i prvostupnicima/magistrima koji ne mogu naći posao ili su u postupku stručnog osposobljavanja. Istraživanje je provedeno u dva navrata tijekom dviju godina. Za analizu motivacije korišten je mjerni instrument Amabile et al. (1994), dok je za analizu privlačnosti poslodavaca korištena skala koji su razradili Berthon et al. (2005). Anketni upitnik sastojao se od tri grupe pitanja: (1) trideset tvrdnji o intrinzičnoj i ekstrinzičnoj motivaciji u kojima su ispitanici na Likertovoj skali od pet stupnjeva (1 - izrazito se ne slažem; 5 - izrazito se slažem) označavali slaganje s ponuđenim tvrdnjama; (2) trideset dva čimbenika privlačnosti poslodavca gdje su ispitanici također na Likertovoj skali (1 - izrazito nevažno, 5 - izrazito važno) označavali važnosti pojedinih čimbenika prilikom izbora poslodavca te (3) nezavisna obilježja ispitanika i to kroz otvoreni tip (dob, fakultet i prosjek) i zatvoreni tip pitanja (spol, studentski status i način financiranja). Uzorak istraživanja čine 165 studenata završnih godina iz 25 hrvatskih fakulteta i veleučilišta. Prikupljeni podatci obrađeni su u programu IBM SPSS 21, a za analizu prikupljenih podataka su osim deskriptivne statistike korišteni i odabrani neparametrijski testovi. Mann Whitneyjev U-test korišten je prilikom usporedbe poželjnih obilježja poslodavaca između dominantno intrinzično i ekstrinzično motiviranih mladih (ordinalna ljestvica, izostanak normalne distribucije) te kako bi se utvrdile razlike između razine motivacije s obzirom na određena nezavisna obilježja ispitanika (spol, dob, područje obrazovanja, studentski status). Kruskal-Wallisov test koristio se za analizu razlika između razine motivacije s obzirom na nezavisna obilježja ispitanika prosjek ocjena i način pokrivanja troškova života.

\subsection{Rezultati istraživanja}

Pouzdanost korištenih mjernih ljestvica potvrđena je Cronbach alfa koeficijentom (privlačnost poslodavca 0,915 ; intrinzična i ekstrinzična motivacija 0,676 ) te se prema Hair et al. (2006) mjerne skale mogu smatrati prihvatljivima s obzirom na to da je Cronbach alfa koeficijent oko 0,6 ili više.

Deskriptivna obrada nezavisnih obilježja ispitanika prikazana je u tablici 1. 
Tablica 1. Prikaz nezavisnih obilježja ispitanika

\begin{tabular}{|l|l|}
\hline $\begin{array}{l}\text { Karakteristike } \\
\text { studenata }\end{array}$ & Pojavnost različitih modaliteta u \% \\
\hline Dob & Do 24 godine 69,1 \%, 25 i više godina 30,9\% \\
\hline Spol & Muško 20 \%, žensko $80 \%$ \\
\hline Područje obrazovanja & Društveno-humanističko 71,5 \%, STEM 28,5\% \\
\hline Studentski status & Redovni 89,7 \%, izvanredni 10,3\% \\
\hline Prosjek ocjena & Do 3,99 - 42,9\%, od 4,00 do 4,49 - 33,8 \%, od 4,5 - 23,3 \% \\
\hline $\begin{array}{l}\text { Način pokrivanja } \\
\text { troškova života }\end{array}$ & $\begin{array}{l}\text { Roditelji } 70,3 \% \text {, samostalno 4,8 \%, samostalno uz malu roditeljsku } \\
\text { pomoć } 24,8 \%\end{array}$ \\
\hline
\end{tabular}

Izvor: obrada autora

Tablica 1 ukazuje da je u uzorku bilo više žena od muškaraca ( $80 \%$ žena), te da su se ispitanici dominantno obrazovali u društvenom ili humanističkom području (71,5 \%). S obzirom na studentski status dominiraju redoviti studenti (89,7\%), dok u pogledu načina financiranja troškova života i studija ima najviše zastupljenih ispitanika čije troškove života i studija pokrivaju roditelji (70,3 \%). Tek 4,8 \% ispitanika iz uzorka samostalno financira sve troškove tijekom studiranja. Istraživanjem su obuhvaćeni mladi s različitim prosjecima tijekom studiranja, pri čemu su svi ispitanici prema prosjeku grupirani u tri skupine: $42,9 \%$ ispitanika imalo je prosjek ocjena manji od $4,00,33,8 \%$ studenata ima prosjek ocjena od 4,00 do 4,49 , dok je $23,3 \%$ studenata imalo prosjek ocjena 4,5 i više.

Tablica 2 sumira rezultate analize prosječne razine intrinzične i ekstrinzične motivacije kod studenata.

Tablica 2. Prikaz prosječne razine intrinzične i ekstrinzične motivacije kod studenata

\begin{tabular}{|l|l|c|c|}
\hline \multirow{2}{*}{ Dob } & Intrinzična motivacija & $\begin{array}{c}\text { Ekstrinzična motivacija } \\
\text { Srednja vrijednost } \\
\text { (standardna devijacija) }\end{array}$ & $\begin{array}{c}\text { Srednja vrijednost } \\
\text { (standardna devijacija) }\end{array}$ \\
\hline \multirow{3}{*}{ Spol } & Do 24 godine & $3,94(0,33)$ & $3,39(0,28)$ \\
\cline { 2 - 4 } & 25 i više godina & $3,85(0,40)$ & $3,39(0,34)$ \\
\hline \multirow{3}{*}{$\begin{array}{l}\text { Područje } \\
\text { obrazovanja }\end{array}$} & Muško & $3,89(0,42)$ & $3,40(0,32)$ \\
\cline { 2 - 4 } & Žensko & $3,91(0,37)$ & $3,39(0,30)$ \\
\cline { 2 - 4 } & humanističko & $3,90(0,36)$ & $3,39(0,31)$ \\
\hline \multirow{2}{*}{$\begin{array}{l}\text { Studenski } \\
\text { status }\end{array}$} & Redoviti & $3,93(0,33)$ & $3,40(0,28)$ \\
\cline { 2 - 4 } & Izvanredni & $3,91(0,33)$ & $3,39(0,29)$ \\
\hline
\end{tabular}




\begin{tabular}{|c|c|c|c|}
\hline \multirow{3}{*}{$\begin{array}{l}\text { Prosjek } \\
\text { ocjena } \\
\text { tijekom } \\
\text { studija* }\end{array}$} & Do 3,99 & $3,88(0,35)$ & $3,34(0,29)$ \\
\hline & Od 4,00 do 4,49 & $3,89(0,34)$ & $3,40(0,29)$ \\
\hline & 4,5 i više & $3,99(0,37)$ & $3,48(0,32)$ \\
\hline \multirow{3}{*}{$\begin{array}{l}\text { Način } \\
\text { pokrivanja } \\
\text { troškova } \\
\text { života }\end{array}$} & Roditelji & $3,88(0,31)$ & $3,37(0,30)$ \\
\hline & Samostalno & $3,89(0,40)$ & $3,46(0,33)$ \\
\hline & $\begin{array}{l}\text { Samostalno uz malu } \\
\text { roditeljsku pomoć }\end{array}$ & $4,00(0,44)$ & $3,44(0,29)$ \\
\hline \multicolumn{2}{|c|}{$\begin{array}{l}\text { Prosječna ocjena (standardna } \\
\text { devijacija) }\end{array}$} & $3,91(0,35)$ & $3,39(0,30)$ \\
\hline
\end{tabular}

Napomena: (standardna devijacija), ${ }^{*}$ statistički značajna razlika između grupa $p=0,056$

$$
\text { Izvor: obrada autora }
$$

Rezultati prikazati u tablici 2 ukazuju da su mladi više motivirani intrinzičnim $(\bar{x}=3,91$, s. d. $=$ $0,35)$ od ekstrinzičnih motivatora $(\overline{\mathrm{X}}=3,39$, s. d. $=0,30)$, te da ne postoje statistički značajne razlike između kategorija mladih s obzirom na promatrana obilježja dob, spol, područje obrazovanja, studentski status i način pokrivanja troškova života. Temeljem provedenog Kruskal-Wallisova testa uočena je statistički značajna razlika između mladih u pogledu prosječne razine ekstrinzične motivacije s obzirom na prosjek ocjena tijekom studija, uz $p<0,1\left(x^{2}=5,764, p=0,056\right)$. Naime, studenti s većim prosječnim ocjenama daju i veću važnost ekstrinzičnoj motivaciji. Primijećeno je i da mladi koji samostalno financiraju troškove studija i života tijekom studija visoko ocjenjuju važnost ekstrinzične motivacije, međutim, ovdje nisu potvrđene statistički značajne razlike između promatranih triju skupina mladih s obzirom na način financiranja troškova života i studija.

Analizom poželjnih obilježja prilikom odabira poslodavca obuhvaćena su 32 moguća obilježja poslodavca. Kao što je prikazano u tablici 3, za visokoobrazovane mlade koji tek izabiru prvog poslodavca izrazitu važnost imaju mogućnost za stjecanje iskustva u struci i dobri odnosi s kolegama. Osim toga, vrlo su važni i podrška kolega, dobar odnos s nadređenima te mogućnost unaprjeđenja u organizaciji. U skupini najmanje poželjnih motiva pokazalo se da veličina organizacije ili djelatnost nemaju posebno veliku važnost prilikom odabira poslodavca. Također, od presudne važnosti nisu ni usmjerenost organizacije na kupce, razvijeno upravljanje kvalitetom i izdašan kompenzacijski paket. 
Tablica 3. Prikaz najpoželjnijih i najmanje poželjnih obilježja prilikom odabira poslodavca

\begin{tabular}{|c|c|}
\hline 5 najpoželjnijih obilježja poslodavaca & 5 najmanje poželjnih obilježja poslodavaca \\
\hline stjecanje iskustva u struci $(\bar{x}=4,58$, s. d. $=0,59)$, & $\begin{array}{l}\text { organizacija koja ima razvijeno upravljanje } \\
\text { kvalitetom }(\bar{x}=3,59 \text {, s. d. }=0,99)\end{array}$ \\
\hline dobri odnosi s kolegama $(\bar{x}=4,56$, s. d. $=0,56)$ & $\begin{array}{l}\text { izdašan kompenzacijski paket }(\bar{x}=3,51 \text {, } \\
\text { s. d. }=0,85)\end{array}$ \\
\hline $\begin{array}{l}\text { kolege koji nas podržavaju i ohrabruju } \\
(\bar{x}=4,43 \text {, s. d. }=0,57)\end{array}$ & $\begin{array}{l}\text { organizacija usmjerena na kupce }(\bar{x}=3,49 \text {, } \\
\text { s. d. }=0,97)\end{array}$ \\
\hline $\begin{array}{l}\text { dobri odnosi s nadređenima ( } \bar{x}=4,41 \text {, } \\
\text { s. d. }=0,58)\end{array}$ & velika organizacija $(\bar{X}=2,92$, s. $d .=0,91)$ \\
\hline $\begin{array}{l}\text { mogućnost za unaprjeđenje unutar } \\
\text { organizacije }(\bar{x}=4,38 \text {, s. d. }=0,69)\end{array}$ & $\begin{array}{l}\text { organizacija iz uslužne djelatnosti ( } \bar{x}=2,90 \text {, } \\
\text { s. d. }=0,92)\end{array}$ \\
\hline
\end{tabular}

Napomena: $\bar{X}=$ srednja vrijednost, s. d. $=$ standardna devijacija

Izvor: obrada autora

U posljednjoj fazi istraživanja cilj je bio utvrditi postoji li razlika između poželjnih obilježja poslodavca s obzirom na razinu interne i eksterne motivacije kod mladih, odnosno postoje li pojedina obilježja poslodavca koja će posebno privlačiti intrinzično/ekstrinzično motivirane ispitanike. Nakon što su mladi podijeljeni u dvije skupine s obzirom na prevladavajući izvor motivacije (intrinzična vs. ekstrinzična motivacija), utvrđeno je da postoje statistički značajne razlike između takvih skupina mladih s obzirom na poželjna obilježja poslodavca (tablica 4).

Tablica 4. Prikaz statistički značajnih razlika poželjnih obilježja poslodavaca između intrinzično i ekstrinzično motiviranih mladih

\begin{tabular}{|l|c|c|c|c|}
\hline \multirow{2}{*}{ Obilježje } & \multicolumn{2}{|c|}{ Srednja vrijednost } & \multirow{2}{*}{$\begin{array}{c}\text { Mann- } \\
\text { Whitneyjev } \\
\text { U-test }\end{array}$} & $\begin{array}{c}\text { Razina } \\
\text { značajnosti } \\
p\end{array}$ \\
\cline { 2 - 3 } & $\begin{array}{c}\text { Intrinzično } \\
\text { motivirani }\end{array}$ & $\begin{array}{c}\text { Ekstrinzično } \\
\text { motivirani }\end{array}$ & $\begin{array}{c}660,000 \\
0,012\end{array}$ \\
\hline dinamična radna okolina & 4,146 & 3,643 & 526,000 & 0,001 \\
\hline inovativni poslodavac & 4,159 & 3,286 & 533,500 & 0,001 \\
\hline $\begin{array}{l}\text { organizacija koja cijeni } \\
\text { i potiče zaposlenikovu } \\
\text { kreativnost }\end{array}$ & 4,331 & 3,500 & 738,000 & 0,046 \\
\hline $\begin{array}{l}\text { organizacija koja nudi } \\
\text { proizvode i usluge visoke } \\
\text { kvalitete }\end{array}$ & 4,040 & 3,429 & 719,000 & 0,034 \\
\hline $\begin{array}{l}\text { organizacija koja nudi } \\
\text { inovativne proizvode }\end{array}$ & 3,887 & 3,286 & & \\
\hline
\end{tabular}




\begin{tabular}{|l|c|c|c|c|}
\hline $\begin{array}{l}\text { organizacija koja } \\
\text { omogućuje primjenu } \\
\text { znanja stečenog na } \\
\text { fakultetu }\end{array}$ & 4,026 & 3,214 & 544,500 & 0,001 \\
\hline $\begin{array}{l}\text { organizacija koja } \\
\text { omogućuje prenošenje } \\
\text { stečenog znanja } \\
\text { pojedinca ostalim } \\
\text { kolegama }\end{array}$ & 4,013 & 3,357 & 693,000 & 0,020 \\
\hline $\begin{array}{l}\text { osjećaj pripadnosti } \\
\text { organizaciji }\end{array}$ & 4,305 & 3,643 & 722,000 & 0,029 \\
\hline $\begin{array}{l}\text { organizacija usmjerena na } \\
\text { kupce }\end{array}$ & 3,543 & 2,857 & 658,000 & 0,014 \\
\hline $\begin{array}{l}\text { izdašan kompenzacijski } \\
\text { paket }\end{array}$ & 3,470 & 3,929 & 763,5 & 0,064 \\
\hline poštena organizacija & 4,411 & 3,929 & 800,500 & 0,093 \\
\hline
\end{tabular}

Izvor: obrada autora

Tablica 4 ukazuje na sva poželjna obilježja poslodavca kod kojih postoji statistički značajna razlika između mladih koji su dominantno intrinzično motivirani i onih koji su dominantno ekstrinzično motivirani. Intrinzično motivirani mladi preferiraju organizacije koje u pogledu načina rada obilježava dinamična radna okolina, gdje se cijeni i potiče zaposlenikova kreativnost te gdje se velika pažnja posvećuje znanju, i to tako da se pojedincima omogućuje primjena znanja stečenog u obrazovnim institucijama, ali i da im se omogućuje da stečena znanja prenose ostalim kolegama. $U$ usporedbi s ekstrinzično motiviranim pojedincima, intrinzično motivirani pojedinci ističu važnost osjećaja pripadnosti organizaciji, što može upućivati na to da će prilikom izbora poželjnog poslodavca prednost dati organizacijama s jakom organizacijskom kulturom.

Intrinzično motivirani pojedinci veću pozornost daju organizacijama koje su usmjerene na kupce te organizacijama koje nude proizvode i usluge visoke kvalitete. Osim toga, kao iznimno važno poželjno obilježje poslodavaca (s najvećom prosječnom ocjenom) intrinzično motivirani pojedinci ističu poštenu organizaciju.

\section{3 Diskusija}

Jedna od ključnih odluka koju mladi donose nakon završetka studija je odabir prvog poslodavca. Pojedincima je u interesu izabrati organizaciju u kojoj će moći iskoristiti sav svoj potencijal te sam izbor organizacije postaje od velike važnosti za buduće zadovoljstvo. Osim usklađenosti s vlastitim ciljevima i sklonostima, u izboru poželjnog poslodavca pojedincima pomaže cjelokupna slika neke organizacije u javnosti, kompenzacije koje nude svojim zaposlenicima, iskustva zaposlenika koji već rade u organizaciji, društvena odgovornost i slični čimbenici. Pritom je tijekom proteklih nekoliko 
desetljeća organizacijama postalo bitno da se diferenciraju od konkurencije kao poželjnija mjesta za rad te ulažu sve veće napore kako bi postali poželjni poslodavci, odnosno marka poslodavca.

Ovim radom analizirali su se unutarnji motivi mladih te uloga dominantnih unutarnjih motiva prilikom odabira poželjnih poslodavaca. Specifične motive koji pojedinca tjeraju na akciju lakše je razumjeti kroz dvije vrste motivacije - intrinzičnu i ekstrinzičnu. Intrinzična motivacija predstavlja urođenu motivaciju da slijedimo vlastite interese i ulažemo napore u traženje izazova koji omogućavaju daljnji razvoj vještina i sposobnosti. $U$ njezinoj se osnovi nalaze prirodne i stečene potrebe, interesi, sposobnosti, sklonosti, stavovi, vrijednosti, očekivanja, kognitivne prosudbe i odluke te emocije. Za razliku od intrinzične motivacije, ekstrinzična motivacija rezultat je poticaja iz okoline i njihovih posljedica i pojavljuje se zbog neke posljedice koja je odvojena od same aktivnosti.

U skladu s dosadašnjim istraživanjima (Wong et al.,2008; Kong et al., 2015), potvrđeno je da su mladi u Hrvatskoj usprkos specifičnim okolnostima koje su obilježile njihov rast i razvoj (rat i ekonomske krize) dominantno intrinzično motivirani. Za sve promatrane kategorije mladih, prosječne ocjene ekstrinzičnih motivatora značajno su niže od intrinzičnih motivatora.

Analiza poželjnih obilježja prvog poslodavca ukazala je da mladi na prvo mjesto stavljaju obilježja koji su intrinzičnog karaktera, što dodatno potvrđuje visoku intrinzičnu motivaciju mladih u Hrvatskoj. Prilikom odabira poslodavca najvažnijim se smatra mogućnost daljnjeg razvoja i napredovanja u struci za koju su se školovali. Vrlo važni motivi mladima su također socijalni motivi, uključujući dobre odnose s kolegama koji su im podržavajući i ohrabrujući te s nadređenima, što je također u skladu s prethodnim istraživanjima (Terjesen et al., 2007; Bellou et al., 2015). Kao što je i ukazalo i istraživanje Arachchige i Robertson (2013), zaključci ovog istraživanja pokazuju da veličina organizacije ili (uslužna) djelatnost nemaju posebno veliku važnost prilikom odabira poslodavca, odnosno da su u odnosu na ostale to manje poželjna obilježja poslodavca.

Među promatranim obilježjima pomalo začuđuje da se izdašan kompenzacijski paket nalazi na začelju ljestvice poželjnih obilježja poslodavaca. Naime, upravo se kompenzacijski paket često ističe kao ključan razlog privlačenja zaposlenika u organizacije, pogotovo mladih (Chhabra, Sharma, 2014; Reis, Braga, 2016), koji su tek na početku karijere te je zadovoljavajući kompenzacijski paket neophodan kako bi mladima omogućio osamostaljenje od roditelja. Ranije provedena istraživanja ukazuju da mladi u Hrvatskoj preferiraju relacijske pred transakcijskim nagradama (Galetić et al., 2015), međutim, u sklopu provedenog istraživanja kompenzacijski paket našao se na popisu najmanje poželjnih obilježja poslodavaca.

$\mathrm{S}$ druge strane, kada se zasebno promatra skupine ispitanike $\mathrm{s}$ obzirom na izvor motivacije, $\mathrm{u}$ skladu s očekivanjima, jedino poželjno obilježje poslodavca koje su važnijim ocijenili ekstrinzično motivirani pojedinci je izdašan kompenzacijski paket. Ovakav nalaz upućuje na to da su mladi koje u osobnom životu motiviraju materijalni čimbenici skloniji prilikom izbora poslodavaca birati organizacije upravo prema tome kriteriju. 


\section{ZAKLJUČAK}

U kontekstu motivacije mladih posebno istraživačko pitanje koje se obrađivalo u sklopu ovog rada je uloga intrinzične i ekstrinzične motivacije kod odabira prvog poslodavca. Pokazalo se da postoji niz značajnih razlika u poželjnim obilježjima poslodavca između dominantno intrinzično i dominantno ekstrinzično motiviranih mladih. Intrinzično motivirani mladi prilikom odabira poslodavca u većoj će mjeri uzeti u obzir obilježja poslodavca koja zadovoljavaju intrinzične potrebe, kao što su primjerice izazovna i dinamična radna okolina te mogućnost za primjenu postojećih znanja ili usvajanje novih znanja. Osim toga, u pogledu same organizacije, birat će organizacije koje će biti poželjne iz pozicije kupca, bilo zbog svoje orijentacije prema kupcima ili kvalitetnih proizvoda. Ekstrinzično motivirani mladi prilikom odabira poslodavca na prvo će mjesto staviti izdašan kompenzacijski paket.

Rezultati istraživanja imaju više praktičnih implikacija. Dobivene spoznaje mogu pomoći poslodavcima u boljem razumijevanju očekivanja mladih posloprimaca i potaknuti ih da se $u$ većoj mjeri posvete zadovoljavanju takvih očekivanja. Poslodavci moraju biti svjesni da mlade ne pokreću isti motivi. Naime, istraživanje je ukazalo da intrinzična motivacija dominira kod visokoobrazovanih mladih u Hrvatskoj te poslodavci, ako žele zadovoljiti takve potrebe, i povećati vlastitu privlačnost, trebaju u okviru primijenjenih sustava nagrađivanja kreirati mehanizme koji će zadovoljiti upravo takve potrebe.

Rad prati nekolicina ograničenja. Osim malog broja ispitanika, valja istaknuti da je anketni upitnik obuhvatio samo manji broj ispitanika koji studiraju na raznim obrazovnim institucijama diljem Republike Hrvatske, što umanjuje reprezentativnost uzorka. U uzorku prevladavaju mladi određenih obilježja: žene i mladi koji su se obrazovali u društveno-humanističkom području, što je potencijalno uvjetovalo dobivene rezultate. Nadalje, istraživanje je pratila nejednaka informiranost ispitanika o istraživanim pojmovima, pojmove kao što su, primjerice, kompenzacijski paket ili upravljanje kvalitetom većinom obrađuju studenti ekonomskog usmjerenja, pa postoji opasnost da su ostali studenti u manjoj mjeri upoznati s ovim pojmovima. Kao ograničenje istraživanja može se istaknuti i mogućnost da su mladi svjesni kako zbog visoke stope nezaposlenosti neće biti u poziciji odabrati željenog poslodavca prema vlastitim preferencijama te su davali općenite društveno poželje odgovore. U budućnosti je poželjno proširiti uzorak istraživanja te uključiti dodatne kontrolne varijable. Također je, budući da generacija Z uskoro ulazi na tržište rada, potrebno provesti istraživanje o poželjnim obilježjima poslodavaca među pripadnicima upravo te generacije. 


\section{LITERATURA}

Amabile, T. M. et al. (1994) "The Work Preference Inventory: Assessing Intrinsic and Extrinsic Motivational Orientations", Journal of Personality and Social Psychology, 66(5), p. 950-967. https://doi.org/10.1037//0022-3514.66.5.950

Arachchige, B. J. H., Robertson, A. (2013) “Employer Attractiveness: Comparative Perceptions of Undergraduate and Postgraduate Students", Sri Lankan Journal of Human Resource Management, 4(1), p. 33- 48. https://doi.org/10.4038/ sljhrm.v4i1.5616

Barić, R. (2012) “Motivacija i prepreke za tjelesno vježbanje”, Arhiv za higijenu rada i toksikologiju, 63(3), p. 47-58

Beck, R. C. (2003) Motivacija: teorija i načela, Jastrebarsko: Slap

Bellou, V. et al. (2015) "Employer Brand of Choice: An Employee Perspective", Journal of Business Economics and Management, 16(6), p. 1201-1215. https://doi.org/10.3846/16111699.2013.848227

Berthon, P., Ewing, M., Hah, L. L. (2005) "Captivating Company: Dimensions of Attractiveness in Employer Branding", International Journal of Advertising, 24(2), p. 151-173. https://doi.org/10.1080/02650487.2005.11072912

Chhabra, N. L., Sharma, S. (2014) “Employer Branding: Strategy for Improving Employer Attractiveness”, International Journal of Organizational Analysis, 22(1), p. 48-60 https://doi.org/10.1108/IJOA-09-2011-0513

Delaney, M. L., Royal, M. A. (2017) "Breaking Engagement Apart: The Role of Intrinsic and Extrinsic Motivation in Engagement Strategies", Industrial and Organizational Psychology, 10(1), p. 127-140. https://doi.org/10.1017/ iop. 2017.2

Dries, N., Pepermans, R., De Kerpel, E. (2008) “Exploring Four Generations' Beliefs about Career", Journal of Managerial Psychology, 23(8), p. 907-928 https://doi.org/10.1108/02683940810904394

Employer Brand International (2014) https://www.employerbrandinternational.com/single-post/2014/06/03/MediaRelease-EBI-Global-Survey-Findings (10. 1. 2019.)

Franca, V., Pahor, M. (2012) "The Strength of the Employer Brand: Influences and Implications for Recruiting", Journal of Marketing \& Management, 3(1), p. 78-122

Galetić, L., Načinović Braje, I., Klindžić, M. (2015) “Adapting reward strategies to millennials' pay preferences”. U: Proceedings of the 5th European Reward Management Conference., Bruxelles: EIASM

Gomes, D., Neves, J. (2011) “Organizational Attractiveness and Prospective Applicants' Intention to Apply", Personnel Review, 40(6), p. 684-699. https://doi.org/10.1108/00483481111169634

Guillot-Soulez, C., Soulez, S. (2014) “On the Heterogenity of Generation Y Job Performances”, Empoloyee Relations, 36(4), p. 319 - 332 https://doi.org/10.1108/ER-07-2013-0073

Hair, J. et al. (2006) Multivariate Data Analysis, 6th. ed. New Jersey: Pearson Educational, Inc.

Jain, N., Bhatt, P. (2015) “Employment Preferences of Job Applicants: Unfolding Employer Brand Determinants”, Journal of Management Development, 34(6), p. 634-652 https://doi.org/10.1108/JMD-09-2013-0106

Kong, H., Wang, S., Fu, X. (2015) “Meeting Career Expectation: Can it Enhance Job Satisfaction of Generation Y?”, International Journal of Contemporary Hospitality Management, 27(1), p. 147-168. https://doi.org/10.1108/ IJCHM-08-2013-0353

Kupperschmidt, B. (2000) "Multigeneration Employees: Strategies for Effective Management", The Health Care Manager, 19 (1), p. 65-76. https://doi.org/10.1097/00126450-200019010-00011

Kuvaas, B. et al. (2017) “Do Intrinsic and Extrinsic Motivation Relate Differently to Employee Outcomes?", Journal of Economic Psychology, 61, p. 244-258 https://doi.org/10.1016/j.joep.2017.05.004

Mannheim, K. (1952) "The Problem of Generations". U: Kecskemeti, P. (ur.) Essays on the Sociology of Knowledge: Collected Works, Volume 5. New York: Routledge, p. 276-322

Montgomery, D. B., Ramus, C.A. (2011) "Calibrating MBA Job Preferences for the 21st Century”, Academy of Management Learning \& Education, 10(1), p. 9-26 https://doi.org/10.5465/AMLE.2011.59513270 
Oblinger, D. (2003) “Boomers, Gen-Xers, and Millennials: Understanding the New Students", Educause Review, 38(4), p. $37-47$

Reeve, J. (2010) Razumijevanje motivacije i emocija, Jastrebarsko: Slap

Reis, G. G., Braga, B. M. (2016) “Employer Attractiveness from a Generational Perspective: Implications for Employer Branding", Revista de Administração, 51(1), p. 103-116 https://doi.org/10.5700/rausp1226

Rheinberg, F. (2004) Motivacija, Jastrebarsko: Slap

Rita, M. et al. (2018) "Moderating Effect of Organizational Citizenship Behavior on the Effect Of Organizational Commitment, Transformational Leadership and Work Motivation on Employee Performance", International Journal of Law and Management, 60(4), p. 953-964. https://doi.org/10.1108/ILLAA-03-2017-0026

Sokro, E. (2012) “Impact of Employer Branding on Employee Attraction and Retention", European Journal of Business and Management, 4(18), p. 164-173

Terjesen, S., Vinnicombe S., Freeman, C. (2007) "Attracting Generation Y Graduates", Career Development International, 12(6), p. 504-522. https://doi.org/10.1108/13620430710821994

Viega, S. M., Gabriel, A. (2016) “The Role of Self-determined Motivation in Job Search: A Dynamic Approach", Journal of Applied Psychology, 101(3), p. 350-361 https://doi.org/10.1037/apl0000070

Wilden, R., Gudergan, S., Lings, I. (2010) “Employer Branding: Strategic Implications for Staff Recruitment”, Journal of Marketing and Management, 26(1-2), p. 56-73 https://doi.org/10.1080/02672570903577091

Wong, M. et al. (2008) "Generational Differences in Personality and Motivation: Do They Exist and What are the Implications for the Workplace?", Journal of Managerial Psychology, 23(8), p. 878-890. https://doi. org/10.1108/02683940810904376

Zhang, J. et al. (2016) "The Different Relations of Extrinsic, Introjected, Identified Regulation and Intrinsic Motivation on Employees' Performance: Empirical Studies Following Self-determination Theory", Management Decision, 54(10), p. 2393-2412 https://doi.org/10.1108/MD-01-2016-0007 


\title{
THE IMPORTANCE OF THE INTRINSIC AND THE EXTRINSIC MOTIVATION FACTORS WHEN CHOOSING THE FIRST EMPLOYER
}

\author{
Ivana Načinović Braje \\ PhD, Assistant Professor, University of Zagreb, Faculty of Economics \& Business, Trg J. F. Kennedyja 6, \\ 10000 Zagreb, Croatia; e-mail: Ivana.nacinovic@efzg.hr \\ Ana Aleksić \\ PhD, Assistant Professor, University of Zagreb, Faculty of Economics \& Business, Trg J. F. Kennedyja 6, \\ 10000 Zagreb, Croatia; e-mail: aaleksic@efzg.hr

\section{Lucija Babok} \\ MA in Economics; e-mail: luche22@gmail.com
}

\begin{abstract}
Employer attractiveness affects employee desire for employment and work in a particular organization. Organizations increasingly make effort to differentiate themselves from others in the sector and to create the image of a desirable employer in the minds of potential employees. At the same time, individuals can engage in action due to various motives, both intrinsic and extrinsic. The purpose of this paper is to determine the type of motivation that drives individuals to achieve their own goals and to identify the role of motivating factors when making a decision about the employment in a particular organization. The objectives of the research are the following: to determine the level of intrinsic and extrinsic motivation of the respondents, to determine important employer features when selecting the first employer and to get an insight into differences in the desirable employer features among dominantly intrinsically and extrinsically motivated respondents. The research was conducted on two occasions over a period of two years using an online questionnaire survey on a sample of 165 respondents, mostly graduate students. Descriptive analysis revealed that the respondents were mostly intrinsically motivated. For highly educated young people the most important factors that defined employer attractiveness were the possibility to gain professional experience and good relations with colleagues. That confirmed a high level of intrinsic motivation among young people in Croatia. A group of least desirable motives was related with organizations themselves - their size and activities.
\end{abstract}

Key words: intrinsic motivation, extrinsic motivation, first employer, generation $Y$ 